\title{
ECOLOGICAL AGRICULTURE AS A FORM OF SUSTAINABLE ENTREPRENEURSHIP ON SOIL
}

\author{
Roman RÉCKY; Jarmila HORVÁTHOVÁ
}

Slovak University of Agriculture in Nitra, Faculty of Economics and Management, Slovakia

\begin{abstract}
Agriculture is a process which should provide a sufficient quantity and quality of foodstuffs for the domestic or foreign market. During its development it has undergone many changes which originated predominantly from the scientific-technical progress in the society and climatic changes. Apart from the foodstuff production, the agriculture executes also the ecological, landscape and social function. Agriculturalists have a significant impact on the environment in which they operate. This impact can be both positive and negative. The negative effect on the natural environment is caused by the excessive utilization of pesticides and commercial fertilizers, production of greenhouse gases, or the excessive irrigation and other interferences into the environment. The ecological agriculture constitutes the alternative to the conventional farming on soil. It represents one of the forms of the sustainable entrepreneurship in agriculture. Apart from the production of fresh and healthy foodstuffs, the ecological agriculture strives to eliminate the negative impacts of agriculture on the environment. The priority is not the quanity, but quality. The ecological function is superior over the economic one. In our paper we analyse the selected aspects of the ecological agriculture in the Slovak Republicc.
\end{abstract}

Key words: agricultural soil, ecological agriculture, mineral fertilizers, pesticides, sustainable agriculture.

\section{Introduction}

For a long time a man earned living by hunting animals or picking berries in the nature. Agriculture ranks among the oldest activities of a man. It originated about 11,000 years ago in the Middle East and allowed the human community to settle permanently at one particular place. Agriculture was spread from the Middle East to other areas and it reached our territory through the Balkans. At that period people acquired the soil for their settlements and fields by grubbing and annihilation of forests. During the long era agriculture went through the difficult development, which depended always on the climatic conditions of the particular area and the development of technologies. Nowadays, just technologies have a significant impact on all spheres of the industrial production and also agriculture. Now, the automatic milking installation serve not only for milking of the farm animals but they contain also the sophisticated information system generating the enormous data which are used for the successful managerial animal husbandry. Similarly, the usage of drones or modern combine harvesters with the different electronic systems is not unusual. Despite of the alleged progress, the primary role of agriculture remains to provide the sufficient quantity of high quality foodstuff for the domestic or foreign market. This fact emphasizes the essential mission of agriculture on one hand, on the other

https://doi.org/10.11118/978-80-7509-820-7-0071

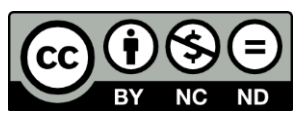


hand, the agricultural basic industry has also the negative impact on the environment. A high level of intensity endangers the quality of soil and other components of environment. The negative effect of agriculture on the environment has predominantly the production of methane in the process of cattle breeding and the excessive utilization of pesticides in the plant production.

The reaction to the deterioration of the environment is the strategy of the European Commission the European Green Deal for 2021 - 2027. This strategy comes from the principal EU objective in the sphere of environment, i.e. the achievement of the climatic neutrality until 2050 . This long-term target means that till 2050 the pure emissions of greenhouse gases, produced by the member states of the EU, will equal zero. It involves several areas, including also the biodiversity protection, sustainable agriculture and the ways of provision of the sustainable food web entitled "Farm to Fork, F2F". The central idea of this approach within the Green Deal is to point out to a new and better equilibrium between the nature, food systems and biodiversity, to protect health and high quality living conditions for our citizens, and at the same time to increase the competitiveness and resistance of EU. According to this philosophy the European foodstuff must be safe, nutritional and of high quality, and the food production must have the minimal impact on the nature. $40 \%$ of the budget of the Common Agricultural Policy should contribute to the measures in the area of climate. In agriculture it refers mainly to the decrease of pesticides usage by $50 \%$, the reduction of nutrition loss in the agricultural soil by $50 \%$, the restriction of fertilizers usage by $20 \%$ and the increase of ratio of agricultural soil cultivated in the ecological way to $25 \%$. All these objectives are planned till 2030 .

The objective of the paper is the evaluation and development analysis of the selected indicators of ecological agricultural production in the Slovak Republic. The article summarizes these indicators and affords a new view of the ecological agriculture, predominantly from the aspect of the ratio indicators.

\section{Literature review / Research Background}

The ecological agriculture originates from the biological approach where the nature constitutes the consistent entity. Its aim is the sustainable and ecologically balances agricultural system producing high quality foodstuffs. The market output of the ecological agriculture are foodstuffs. In order to apply them successfully on the market it is required to know the needs, possibilities and interest of consumers (Kretter 2005, p. 7).

In the protection of environment the agriculture also plays a significant role. Apart from the traditional production function it executes other, equally important functions, i.e. social, societal as well as landscape ones (Horská, Nagyová at all, 2013, p. 7).

The fundamental factor of the sustainable farming on soil is the competitiveness of the agricultural producers. Here the decisive role is played by the remittance of costs by the prices of commodity outputs and other compensations usually from the 
public funds. These funds settle the costs of non-commodity outputs (environmental services), which so far cannot be evaluated via market (Blass, Bielek, Božík. 2010, p. 8).

The ecological farming brings higher revenues for commodities to agriculturalists, on the other hand, it means lower yields, more profound registration of activities or the necessity of usage of slower, mechanical weed-control in comparison with faster application of the chemical preparations (4).

The European Commission enforces sustainability in agriculture and rural areas across EU through the Common Agicultural Policy. (CAP). The CAP aims to ensure that agriculture and forestry in the EU is socially, economically and environmentally sustainable. The transition to sustainable agriculture in the EU is driven by new technologies, research and innovation, and the spread of knowledge. The CAP sets out to tackle climate change, protect natural resources and enhance biodiversity in the EU (European Commission, 2021).

As of the end 2019, 16.5 million hectares of agricultural land in Europe (European Union: 14.6 hectares) were managed organically by over 430,000 producers (European Union: almost 344,000). In Europe 3.3 percent of the agricultural area was organic (European Union: 8.1 percent). The countries with the largest organic agricultural areas were Spain (2.4 million hectares), France (2.2 million hectares) and Italy (2.0 million hectares). In twelve countries, at least 10 percent of the farmland was organic: Liechtenstein has the lead (41.0 percent), followed by Austria (26.1 percent) and Estonia (22.3 percent). Retail sales of organic products totalled 45.0 billion euros in 2019 (European Union: 41.4 billion euros) (FiBL\&IFOAM Organics International, 2021).

\section{Methodolody}

In the paper the methods of analysis, synthesis, comparison and simple mathematical and statistical methods have been used. The required data have been acquired mainly from the secondary sources of the Ministry of Environment and Ministry of Agriculture and Rural Development of the SR, and the Statistical Office of the SR.

\section{Results}

Agriculture has a significant impact on the environment not only by its landscape function but it affects also soil, water and atmosphere. The agricultural production can be based on the conventional, environmental, ecological, sustaining or combined principle. The agricultural activity causes soil degradation, emissions of greenhouse gases, waste generation and pollution of atmoshere and releasing of sewage water. Recently, in the agricultural sector we can observe the movement from the market oriented conception towards the conception of the sustainable marketing, which apart from the economic growth emphasizes also the long-term effects that have been caused by the agricultural activity in the environment. The priority is the preservation 
of biodiversity of the whole system and prevention of its degradation. As in some regions the traditional form of conventional agriculture seems to be unattractive and uneconomic, nevertheless, it is necessary to retain and cultivate the landscape, therefore, in these areas it is appropriate to concentrate on some of the alternative forms of the agricultural production. One of them is the ecological agriculture as a way to secure the sustainability of the regions. The ecological agriculture is the system that respects the life cycle of the natural systems and provides the quality, healthy, fresh, tasty and genuine foodstuff to the consumers. The rules of the ecological agricultural production in the Slovak Republic are being regulated by the Act No. 282/2020 Collection of Laws on the ecological agricultural production, which has amended the original Act No. 189/2009. The ecological agriculture is the area of the agricultural production which develops rapidly in the EU countries, including Slovakia. This development constitutes the consequence of the increased consumers' interest in bio food, and also the response to the changes in the field of environment. From the January 1, 2022 EU will introduce new regulations targeted at the effectiveness in this sphere. There will be also new rules for the producers that simplify the transition to the ecological production for small farmers and reinforce the system of controls in order to build consumers' trust in the system of ecological agricultural production.

In 2019, the EU's total area of farmland under organic production grew to 14.6 million hectares. Compared to 2018, the number of organic producers in the EU increased by $5.1 \%$ to 343,858 . A significant growth of the EU's organic retail market accompanies this development, rising by $12 \%$ to 41.5 billion EUR. Between 2010 to 2019, the value of the EU's organic market more than doubled (IFOAM Organics Europe, 2021).

The development of the selected indicators of the organic agriculture in Slovakia in 2003 - 2019 is indicated in the Table 1. The table records the development of size of ecologically cultivated soil, number of farms of the ecological agriculture and the average size of these farms. As the table indicates the first three evaluated indicators show the rising trend, and the average size of farms is falling. The area of ecologically cultivated agricultural soil (including the areas in- conversion) was increased from 54, 479 ha to 196, 210 ha, which is the growth by 141,731 ha. Even more significant rise was recorded with the ratio of ecologically cultivated agricultural soil out of the total area of the agricultural soil. In 2003 in Slovakia $2.20 \%$ of agricultural soil was cultivated ecologically, in 2019 it was $10.24 \%$ out of the total area, which was the growth $8.04 \%$. The objective is to achieve the level of min. $13.5 \%$ till 2030. The most considerable increase is evident in the number of the farms using the principles of the ecological agriculture. In 2019 there were 567 farms, in 2003 only 88, which is the growth by 479 farms. The average area of the farm is decreasing. From 2003 to 2019 this fall was 273.1 ha. 
Table 1. Development of selected indicators of ecological agriculture

\begin{tabular}{|c|c|c|c|c|}
\hline Year & $\begin{array}{l}\text { Area of } \\
\text { ecologically } \\
\text { cultivated agr. } \\
\text { soil (ha) }\end{array}$ & $\begin{array}{l}\text { Ratio of } \\
\text { total agr. } \\
\text { soil (\%) }\end{array}$ & $\begin{array}{l}\text { Number of } \\
\text { farms of } \\
\text { ecological } \\
\text { agriculture }\end{array}$ & $\begin{array}{l}\text { Average } \\
\text { area of } \\
\text { farms (ha) }\end{array}$ \\
\hline 2003 & 54,479 & 2.20 & 88 & 619.1 \\
\hline 2004 & 65,400 & 2.18 & 131 & 499.2 \\
\hline 2005 & 92,191 & 4.93 & 210 & 439.0 \\
\hline 2006 & 121,956 & 6.42 & 256 & 476.4 \\
\hline 2007 & 123,819 & 6.52 & 280 & 442.2 \\
\hline 2008 & 136,669 & 7.25 & 349 & 391.6 \\
\hline 2009 & 146,762 & 7.50 & 385 & 381.2 \\
\hline 2010 & 178,235 & 9.23 & 410 & 437.7 \\
\hline 2011 & 180,261 & 9.34 & 364 & 495.2 \\
\hline 2012 & 168,602 & 8.43 & 362 & 465.7 \\
\hline 2013 & 162,029 & 8.40 & 341 & 475.2 \\
\hline 2014 & 180,365 & 9.39 & 399 & 452.0 \\
\hline 2015 & 186,483 & 9.70 & 416 & 448.2 \\
\hline 2016 & 187,010 & 9.75 & 430 & 434.9 \\
\hline 2017 & 189,147 & 9.90 & 439 & 430.9 \\
\hline 2018 & 192,143 & 10.02 & 535 & 359.1 \\
\hline 2019 & 196,210 & 10.24 & 567 & 346.0 \\
\hline $\begin{array}{l}\text { Index } \\
19 / 03\end{array}$ & 3.60 & 4.65 & 6.44 & 0.59 \\
\hline
\end{tabular}

Source: Author`s processing according to the data of the Central Control and Testing Institute in Agriculture

The Table 2 describes the development of the total used arable soil and the ratio of the soil registered in the ecological system of agriculture (ESA) in 
2012-2019. We evaluate the similar development also with the permanent grasslands (PG). The area of the total used arable soil decreased by 11, 060 ha (1\%). The territory of the arable soil registered in the ecological agricultural production (EAP) was increased from 54,264 ha to 66,560 ha (growth by $23 \%$ ). Out of the total arable soil the ecological agricultural production constitutes $4.93 \%$. The permanent grasslands registered in the ecological agricultural production achieved a higher ratio of the total permanent grasslands in the whole evaluated period. In the last evaluated year this ratio was almost $25 \%$. The total are of these premises is relatively stable. In 2019 the level achieved 518,415 ha, during the whole period it increased by 14,544 ha $(1 \%)$.

In 2019 the average ratio of the soil under ecological cultivation in the EU was 8.5\%. From this aspect Slovakia has more soil under ecological cultivation (by $1.74 \%$ ) than the average of the EU. According to the strategy "From Farm to Table" the ratio of this type of cultivation should be increased to $25 \%$ in 2030. Nowadays, only Austria achieves this level out of the EU member countries. In order to achieve this objective the Council of EU promised to provide $20 \%$ of the direct payments for the ecological regimes.

Table 2. Development of areas of agricultural soil according to the type of plot

\begin{tabular}{|c|c|c|c|c|c|c|}
\hline Year & $\begin{array}{c}\text { Used arable } \\
\text { soil } \\
\text { in total (ha) }\end{array}$ & $\begin{array}{c}\text { Arable } \\
\text { soil } \\
\text { in EAP } \\
\text { (ha) }\end{array}$ & $\begin{array}{l}\text { Arable } \\
\text { soil } \\
\text { in EAP } \\
\text { (\%) }\end{array}$ & $\begin{array}{l}\text { grasslands } \\
\text { in total } \\
\text { (ha) }\end{array}$ & $\begin{array}{c}\text { Permanent } \\
\text { in EAP } \\
\text { (ha) }\end{array}$ & $\begin{array}{c}\text { Permanent } \\
\text { in EAP } \\
\text { (\%) }\end{array}$ \\
\hline 2012 & $1,359,979$ & 54,264 & 3.99 & 514,942 & 113,075 & 21.96 \\
\hline 2013 & $1,362,002$ & 53,181 & 3.90 & 513,704 & 107,622 & 20.95 \\
\hline 2014 & $1,359,091$ & 62,279 & 4.58 & 510,801 & 116,528 & 22.81 \\
\hline 2015 & $1,350,180$ & 60,890 & 4.51 & 520,581 & 123,855 & 23.79 \\
\hline 2016 & $1,347,293$ & 60,302 & 4.47 & 521,441 & 124,807 & 23.94 \\
\hline 2017 & $1,342,885$ & 62,978 & 4.69 & 517679 & 124,230 & 23.80 \\
\hline 2018 & $1,348,019$ & 64,821 & 4.81 & 523,552 & 125,366 & 23.95 \\
\hline 2019 & $1,348,919$ & 66,560 & 4.93 & 518,415 & 127,619 & 24.62 \\
\hline Index & 0.99 & 1.23 & 1.24 & 1.01 & 1.13 & 1.12 \\
\hline $19 / 12$ & & & & & & \\
\hline
\end{tabular}

Source: Author`s processing according to the data of Green Report 


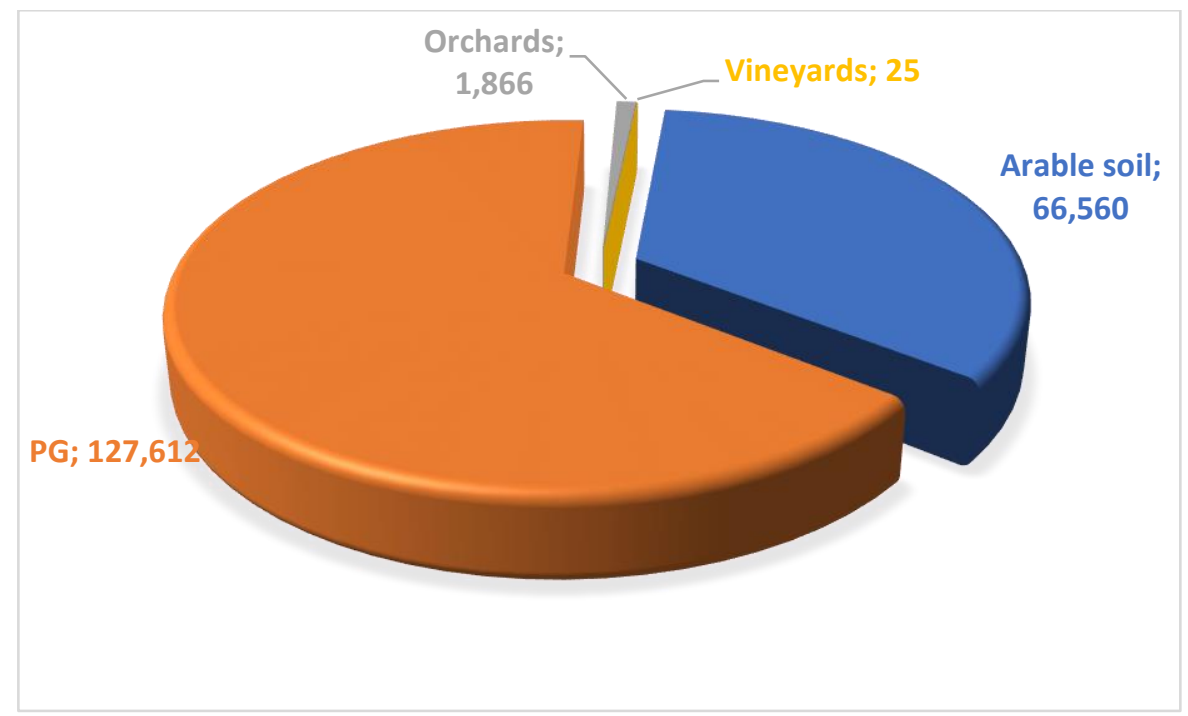

Figure 1. Agricultural soil registered in ESPA in 2019 according to the type of plot (ha)

Source: Author`s processing according to the data of Green Report 2020

The area of ecologically cultivated agricultural soil according to the type of plot in 2019 is indicated in the Figure 1. In the long term the highest ratio is represented by permanent grasslands which created $65.0 \%$ out of the total area of ecologically cultivated agricultural soil, followed by arable soil (33.9\%) and orchards $(1 \%)$. The area of the ecologically cultivated vineyeards was neglectable (25 ha). These data indicate that the permanent grass covers (meadows and pastures) can most easily be ecologically cultivated. On the other hand, it is very difficult to cultivate ecollogically vineyards, and at the same time to achieve the positive trading income. The same situation is related to fruit growing. In Slovakia the permanent grass covers are being used predominantly for sheep breeding, therefore in this category of farm animals the ecological approach prevails.

In this part we analyze the selected indicators of the animal husbandry of the ecological agricultural production (EAP). The Table 3 involves the development of the numbers of the farm animals registered in EAP in 2012 - 2019. The table indicates sheep, cattle, poultry, goats, pigs, horses and the total number of animals. It also includes the animals in-conversion. The Table 4 shows the percentage representation of the individual categories of farm animals of the total number of animals in the particular category. In the total evaluation the highest number was achieved by sheep. The number of sheep raised in EAP was decreased by 10,372 pieces $(10 \%)$. Sheep grown ecologically form $30.2 \%$ out of the total number of sheep raised in Slovakia. The number of cattle was increased by 20,951 (48\%). Out of the total number of cattle almost $15 \%$ are raised in EAP. 
Table 3. Development of number of farm animals according to the types raised in EAP (pieces)

\begin{tabular}{|l|l|l|l|l|l|l|l|}
\hline Year & Sheep & Cattle & Poultry & Goats & Pigs & Horses & Total \\
\hline 2012 & 107,327 & 43,293 & 8,849 & 2,052 & 146 & 611 & 162,278 \\
\hline 2013 & 106,713 & 43,142 & 8,708 & 1,979 & 187 & 659 & 161,388 \\
\hline 2014 & 96,976 & 44,772 & 8,250 & 1,005 & 175 & 569 & 151,747 \\
\hline 2015 & 97,239 & 58,945 & 4,110 & 1,527 & 503 & 643 & 162,967 \\
\hline 2016 & 93,596 & 65,724 & 5,311 & 1,429 & 438 & 590 & 167,088 \\
\hline 2017 & 102,000 & 61,655 & 4,111 & 1,349 & 164 & 541 & 169,820 \\
\hline 2018 & 84,912 & 63,340 & 5,340 & 1,419 & 547 & 541 & 156,099 \\
\hline 2019 & 96,955 & 64,244 & 6,316 & 1,814 & 732 & 529 & 170,590 \\
\hline $\begin{array}{l}\text { Index } \\
19 / 12\end{array}$ & 0.90 & 1.48 & 0.71 & 0.90 & 5.01 & 0.87 & 1.05 \\
\hline
\end{tabular}

Source: Author`s processing according to the data of Green Report and Statistical Office SR

Table 4. Ratio of selected categories of farm animals raised in EAP out of the total number of animals (\%)

\begin{tabular}{|c|c|c|c|c|c|c|}
\hline Year & Sheep & Cattle & Poultry & Goats & Pigs & Total \\
\hline 2012 & 26.2 & 9.2 & 0.1 & 5.9 & 0.0 & 8.28 \\
\hline 2013 & 26.7 & 9.2 & 0.1 & 5.6 & 0.0 & 8.32 \\
\hline 2014 & 24.8 & 9.6 & 0.1 & 2.9 & 0.0 & 7.48 \\
\hline 2015 & 25.5 & 12.9 & 0.0 & 4.2 & 0.1 & 8.54 \\
\hline 2016 & 25.4 & 14.7 & 0.0 & 3.9 & 0.1 & 8.82 \\
\hline 2017 & 27.9 & 14.0 & 0.0 & 3.6 & 0.0 & 9.10 \\
\hline 2018 & 24.2 & 14.4 & 0.0 & 3.8 & 0.1 & 8.50 \\
\hline 2019 & 30.2 & 14.9 & 0.1 & 5.1 & 0.1 & 10.08 \\
\hline Index 19/12 & 1.15 & 1.62 & 1.00 & 0.86 & - & 1.22 \\
\hline
\end{tabular}

Source: Author`s processing according to the data of Green Report and Statistical Office SR 
We can observe the decrease of the number of poultry, goats and horses. The number of poultry and pigs raised in EAP represents only a small ratio $(0,1 \%)$ out of the total number of these categories. The figure of pigs fluctuates, in the whole evaluated period there was fivefold growth of their number. The total number of animals grown in EAP recorded the increase by 8,312 pieces (5\%). A higher growth is evident in the ratio of animals raised in EAP out of the total number of farm animals $(10 \%)$. This trend is caused not only by the growth of the total number of animals rasied in EAP, but also by the continuous fall of the total number of farm animals grown in Slovakia.

In this part we will focus attention on the negative impacts of agriculture on the environment. We will evaluate the development of consumption of pesticides and mineral fertilizers. The pesticides are the preparations used in agriculture for the crop protection against the animal and plant pests and fungal diseases. From 1990 the usage of pesticides and mineral fertilizers has been decreasing. This tendency was stopped in 2005 and from this year there has been recorded the growth.

The development of the total consumption of pesticides in agriculture in SR in $2012-2019$ is indicated in the Figure 2. The usage of pesticides is being increased continuously and in the evaluated period it was risen by 1,587 tonnes. In 2019 out of pesticides mostly herbicides were used $(2,679 \mathrm{t}), 1,265 \mathrm{t}$ fungicides, $475 \mathrm{t}$ insecticides, $422 \mathrm{t}$ fungal and insecticidal desinfectants and $680 \mathrm{t}$ of other pesticides. According to the plans of the EU the utilization of pesticides should have been decreased by a half until 2030. According to the authors of this paper, the achievement of this objective will be difficult, as the usage of pesticides was growing in the most EU member states in 2011 - 2019. The decrease was monitored only in seven countries, Portugal was in the lead (drop by $42 \%$ ). 


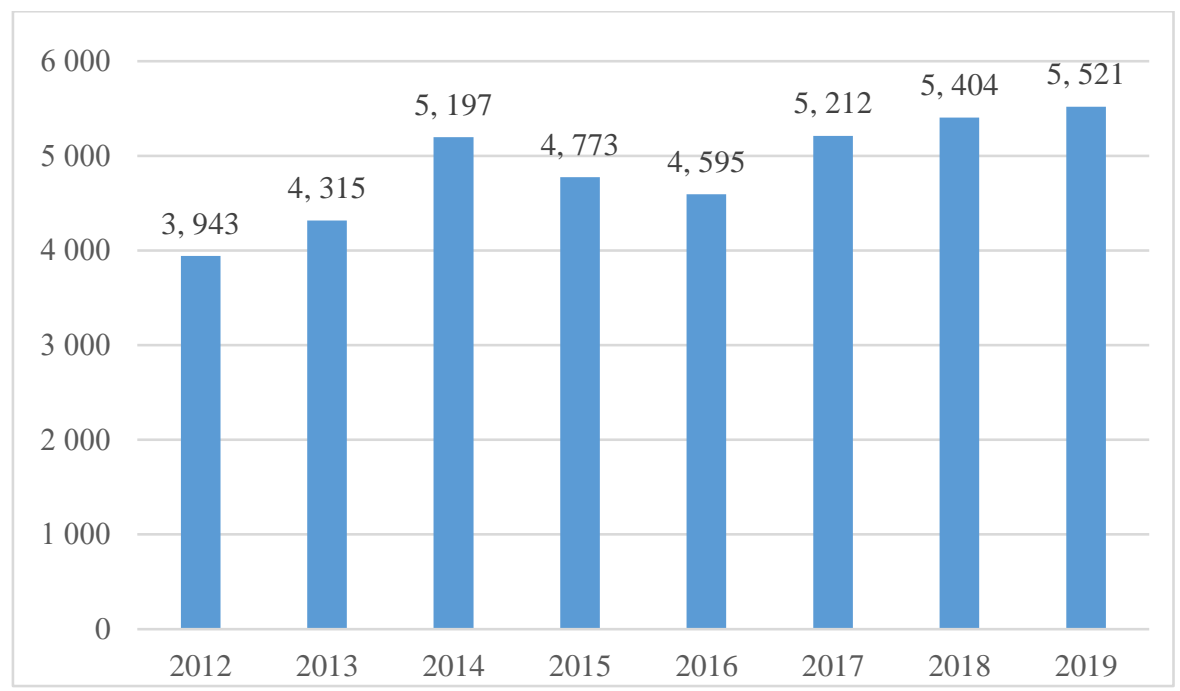

Figure 2. Development of consumption of pesticides in agriculture of SR

$$
\text { in } 2012-2019(t)
$$

Source: Author`s processing according to the data of the Central Control and Testing Institute in Agriculture

The consumption of the mineral fertilizers (NPK) in kilograms of the pure nutrients per hectare of the agricultural soil in SR during the period 2012 - 2019 is indicated in the Figure 3. In 2021 it was 85.8 kg.ha-1, in $2019102.8 \mathrm{~kg}^{-h^{-1}}$, which means the growth by $17.0 \mathrm{~kg} \cdot \mathrm{ha}^{-1}$. The lowest usage was monitored in 2016 $\left(88.2 \mathrm{~kg} \cdot \mathrm{ha}^{-1}\right)$. 


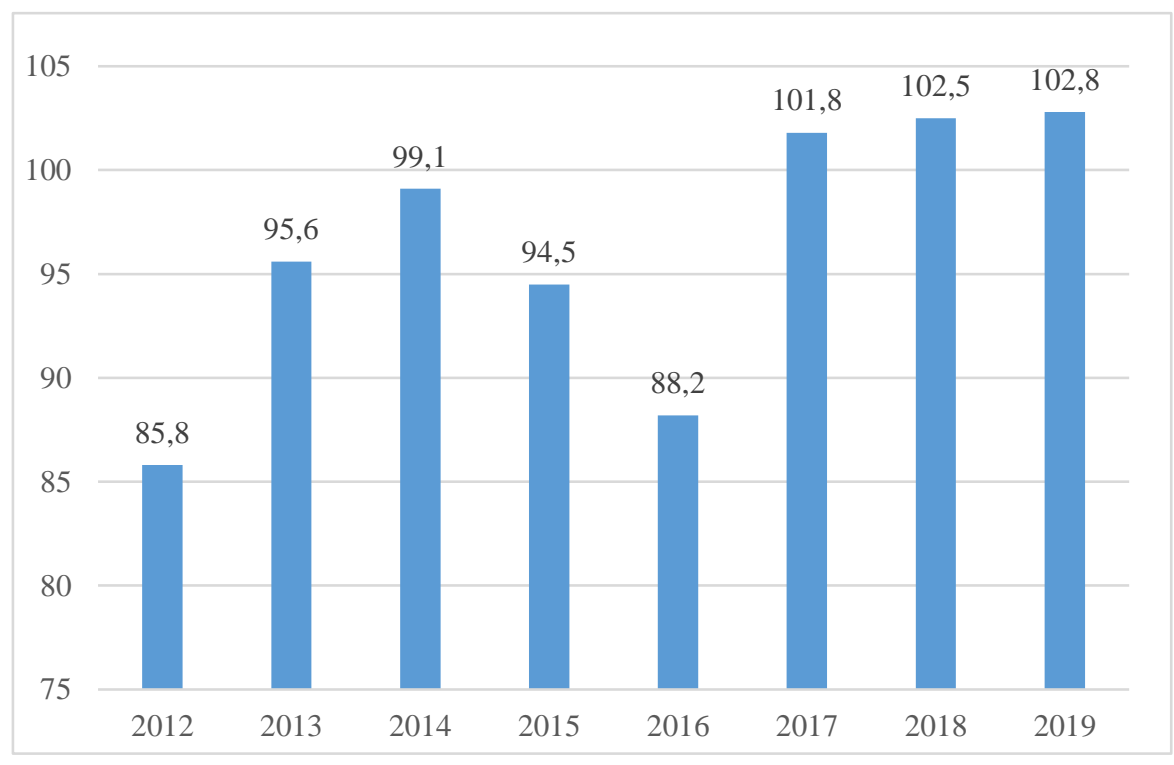

Figure 3. Deveolpment of consumption of mineral fertilizers in agriculture of SR in 2012 - 2019 (kg.ha $\left.{ }^{-1}\right)$

Source: Author`s processing according to the data of the Central Control and Testing Institute in Agriculture

\section{Conclusion}

The primary mission of agriculture is to provide the sufficiency of secure and high quality foodstuff needed for the nutrition of the population. For a longer time the emphasis is placed also on other extra-productive functions of agriculture. The most significant ones are the provision of the sustainable utilization of the natural resources and preservation of vigorous countryside. The idea of the sustainable development in agriculture is met by the ecological agriculture, which represents the alternative conception of the agrarian policy and strives for the continuous production of the healthy foodstuffs in the way which is environmentally friendly.

The interest in the organic form of farming on soil is being inceased constantly. In 2019 the area of ecologically culticated agricultural soil achieved 196,210 ha. Out of the total agricultural soil it is more than $10 \%$. According to the type of plots the highest rate of ecologically cultivated areas are the permanent grassland $(127,612 \mathrm{ha})$ and arable soil $(66,560 \mathrm{ha})$. The total number of the registered producers was 859 , farmers 567 . We can see the constant growth also in these indicators.

The increase is evident also in the total number of animals raised in EAP. The total growth is 8,312 pieces ( $5 \%$ ). The highest number is achieved in growing sheep, followed by cattle. The ratio of pigs and poultry is very low. Out of the total number of raised animals more than $10 \%$ is grown in the ecological breeding. 
The agriculture effects the environment in the different ways, including the usage of pesticides and mineral fertilizers. In 2019 the total consumption of pesticides in agriculture was 5,521 tonnes. In comparison with 2012 there was the growth by 1,587 tonnes $(40 \%)$. We can record also the growth in the development of the usage of mineral fertilizers. In 2012 it was the lowest level $\left(85.8 \mathrm{~kg}^{2} \mathrm{ha}^{-1}\right)$, in 2019 it achieved the highest number $\left.102.8 \mathrm{~kg} \cdot \mathrm{ha}^{-1}\right)$. In total there was the growth by $17 \mathrm{~kg} \cdot \mathrm{ha}^{-1},(20 \%)$.

The organic agriculture ranks among the alternative ways of farming on soil with a great perspective of the further development arising from the urgent needs of the society and increased demand for bio-foodstuff. In the future period the faster development of ecological agriculture in EU and Slovakia can be facilitated by the Common Agriculture Policy with the subsidies for this form of farming on soil.

\section{References}

1. Kretter, A. (2005), Marketing ekologického pol'nohospodárstva a ekoproduktov, Nitra, SPU v Nitre, 90 .s. ISBN 80-8069-620-9.

2. Horská, E., Nagyová, L. a kol. (2013), Marketinové prístupy k udržatel’nosti agrosektora na Slovensku Nitra,SPU v Nitre, 191 .s. ISBN 978-80-552-1126-8.

3. Blass,G., Bielek, P.,Božík, M. (2010). Pôda a polnohospodárstvo. Úvahyo budúcnosti. Bratislava, VÚPaOP, 40 s. ISBN 978-80-89128.

4. Pol'noinfo.sk . Aktuálny pohl'ad na agrosektor. 2021. [online]. [cit. 2021-04-26]. Retrieved from: https://pol'noinfo.sk/ seststo-eur-za-slnecnicu-ci-osemsto-za-repku-sustandardnou-cenou/ .

5. Enviroportál. Informačný portál rezortu MŽP SR. 2005 - 2021. [online]. [cit. 2021-0422]. Retrieved from: https://www.enviroportal.sk/spravy/detail/10361?p=9341

6. Zelená správa. MPRV 1998- 2021. . [online]. [cit. 2021-04-26]. Retrieved from: https://www.mpsr.sk/zelena-sprava-2020/122---16206/.

7. EUR Lex. 2021. [online]. [cit. 2021-03-22]. Retrieved from: https://eurlex.europa.eu/resource.html?uri=cellar:b828d165-1c22-11ea-8c1f01aa75ed71a1.0018.02/DOC_1\&format=PDF.

8. Európska zelená dohoda. 2021. [online]. [cit. 2021-04-29]. Retrieved from: https://www.minzp.sk/klima/europska-zelena-dohoda/.

9. European Green Deal. 2021. [online]. [cit. 2021-03-22]. Retrieved from: https://ec.europa.eu/info/strategy/priorities-2019-2024/european-green-deal/actionsbeing-taken-eu/farm-fork_sk.

10. FiBL\&IFOAM Organics International, 2021. [online]. [cit. 2021-05-24]. Retrieved from: https://www.fibl.org/fileadmin/documents/shop/1150-organic-world-2021.pdf.

11. IFOAM Organics Europe, 2021. [online]. [cit. 2021-05-24]. Retrieved from: https://www.organicseurope.bio/about-us/organic-in-europe/.

12. Spotreba prípravkov na ochranu rastlín. ÚKŠÚ. 2019 - 2021. [online]. [cit. 2021-0322]. Retrieved from: https://www.uksup.sk/spotreba-pripravkov-na-ochranu-rastlin.

13. Sustainable agriculture in EU. [online]. [cit. 2021-05-24]. Retrieved from: https://ec.europa.eu/info/food-farming-fisheries/sustainability_en. 